\title{
Preparation of Bio Yoghurt Cereal Fermented Milk
}

\author{
Effat, Gouda; Abbas, Malak and Farag, Marian ${ }^{1}$
}

\begin{abstract}
This work aimed to produce probiotic fermented milk supplemented with cereals using three different concentrations $(3,5$ and $7 \%$ ) of whole wheat flour (wwf) and whole barley flour (wbf) and bioyoghurt starter ABT2, CHB Hansen. The changes in the chemical composition ,microbial and sensory evaluation of fresh products during two weeks of storage at $5-7^{\circ} \mathrm{C}$ were determined. The rate of decreasing in $\mathrm{pH}$ and increasing in acidity of wheat flour fermented bioyoghurt was lower than that in control either in fresh or after storage period. The same trend was found during the storage of barley fermented bioyoghurt but the rate of $\mathrm{pH}$ decreasing and acidity increasing was higher in wbf than that in wwf fermented bioyoghurt .Total protein and fiber were increased in cereal fermented bioyoghurt in accordance to the \% of wheat or barley flour added. On the other hand the soluble protein/total protein was increased during storage in both because of protein degradation by microorganism. The effect of both wheat or barley flour showed higher viscosity in the fresh product and after storage. The $\log 10 \mathrm{cfu} / \mathrm{gm}$ of control in fresh product and after 14 days of storage were 6.545 and 6.220 respectively which decreased to 5.819 and 5.114 on lithum chloride sodium propionate medium. Adding whole flour by $3 \%$ increased the $\log 10 \mathrm{cfu} / \mathrm{gm}$ in the fresh products and after 14 days of storage to 6.5556 and 6.255 resp, on LCSP medium. The same trend of enhancing probiotic culture by adding whole flour was noticed when furthermore $3 \%$ wbf was added. Non of the undesirable microorganism were detected (coliform, yeast and mould) in fresh or stored products. $3 \%$ bioyoghurt wheat flour and $5 \%$ whole barley flour exhibit the best acceptance dependent on the sensory evaluation.
\end{abstract}

\section{INTRODUCTION}

Functional foods are defined broadly as foods that provide more than simple nutrition; they supply additional physiological benefit to the consumer .According to the Functional Food Science in Europe, a food can be regarded as "functional" if it is satisfactorily demonstrated to affect beneficially one or more target functions in the body, beyond adequate nutritional effects, in a way that is relevant to an improved state of health and well- being and / or reduction of risk of disease (Saarela, 2007). These functional foods are approved on the basis of scientific evidence for reducing risk of disease but it is not intended to act as disease treatment .Functional foods must remain foods, and they must demonstrate their effects in amounts that can normally be expected to be consumed in the diet (Diplock et al., 1998).

Probiotics are usually defined as microbial food supplements with beneficial effects on the consumers. Most probiotics found in the group of organisms known as lactic acid - producing bacteria and are normally consumed in the form of fermented milks or other fermented foods. Some of the beneficial effect of lactic acid bacteria consumption include improving intestinal tract health , enhancing the immune system, synthesizing and enhancing the bioavailability of nutrients , reducing symptoms of lactose intolerance, decreasing the prevalence of allergy in susceptible individuals, reducing risk of certain cancers, anticholesterolaemic effects, prevention of genital and urinary tract infections Savadogo et al.,(2006). However, for a strain to be considered a valuble dietary adjunct exerting a positive influence, it has to full fill certain criteria .A good probiotic strain for human use could have properties of the following list: Human origin, survival in the upper digestive tract, capable of surviving and growing in the intestine, produce beneficial effects when in the intestinal tract, resistance to acid and bile salts, safe status, production of antimicrobial substances like bacteriocins, and adherence to human intestinal cell lines and colonization (Sander, 2003).

Fermented dairy products are the most commonly used vectors for probiotic. Conventional products such as yoghurt and cultured milk are usually contain bacterial population of around $10{ }^{8}$ living bacterial cells per gram .The probiotic bacteria may either contribute to fermentation and acidification; i.e., Lactobacillus acidophilus or they can be regarded as pure additives; i.e., Bifidobacterial strains .Their viability during fermentation and storage conditions can be regarded as cardinal points determining the specific quality of the food (Kneifeletal.,1999).

Today, abroad variety of fermented and nonfermented dairy products containing lactic acid bacteria with probiotic function is available on the market .They must be selected for their ability to provide the targeted benefit for the consumer .Historically, fermented milks have been regarded as valuable and sensorically attractive foods which positively influence the intestinal microbial balance of humans (Abd El-Rahman et al, 2000).

\footnotetext{
${ }^{1}$ University of Alexandria- Faculty of Agriculture

Department of Dairy Science and Technology

Received April 03, 2013, Accepted June 10, 2013
} 
This work aimed to produce probiotic fermented milk supplemented with cereals such as wheat and barley as a functional food for the purpose of increasing the beneficial values of fermented milk.

\section{MATERIALS AND METHODS}

\section{Ingredients:}

Dried whole milk $(24.4 \%$ protein, $28.8 \%$ fat, $37.8 \%$ carbohydrates, $0.58 \%$ ash and $3.3 \%$ moisture) produced from BBA-Lactalis industrie 35230 Bourgarre-France.

\section{Cereals}

Whole wheat flour (Triticum restivum): whole grains from the local market were washed, dried and crushed. The gross chemical composition of whole grains after analysis were $9.7 \%$ protein, $0.58 \%$ fat, $72.85 \%$ carbohydrate, $0.87 \%$ ash, $10 \%$ moisture and 6.0 $\%$ crude fiber.

Whole barley flour (Hordeum vulgare): were purchased from local markets. Then washed, dried and crushed. The gross chemical composition of whole grains were $11.7 \%$ protein, $1.88 \%$ fat, $67.17 \%$ carbohydrate, $1.9 \%$ ash, $7 \%$ moisture and $10.35 \%$ fiber.

Starters:- Bio-yoghurt starter (ABT-2) (CHR HANSEN) Streptococcus thermophilus-20 y, Lactobacillus acidophilus LA- 5, Bifidobacterium BB12

\section{Manufacturing of Bio- yoghurt cereal fermented milk products:}

The whole milk powder was reconstituted to obtain $12 \%$ T.S. Three levels of cereals powder were used (3,5and $7 \%$ ) for each whole flour tested. The cereals were added before heat treatments at $85^{\circ} \mathrm{C} / 15 \mathrm{~min}$, then cooled at $40^{\circ} \mathrm{c} .3 \%$ of starter was added, then distributed in plastic cups (100gm each) and incubated at 37c till complete coagulation, cooled and stored at $5 \pm 1^{\circ} \mathrm{c}$.

\section{Chemical and Rheological analysis}

The samples were analyzed in triplicates for $\mathrm{pH}$, titratable acidity as lactic acid, volatile acidity, viscosity, acetaldehyde (ppm), were determend, in the fresh products and after $4,7,14$ days of storage at $5 \pm 1{ }^{\circ} \mathrm{C}$, while, total solides total protein, carbohydrate, ash, crude fibers and fat content were determined only in the fresh products.

Total solids, $\mathrm{pH}$ value, (Accumet ${ }^{\circledR}$ model $810 \mathrm{pH}$ meter, Fisher scientific), Titratable acidity $\%$, Volatile acidity $\%$, total protein $\%$, soluble protein $\%$, Crude fibers\% and Ash \%were determined according to the methods described in the AOAC (2003).

Viscosity was measured at $20^{\circ} \mathrm{C}$ using rotary viscometer "Rheotest" Type RV, Dresden, Germany.. The viscosity was expressed in centipoises and calculated by using special formulas and tables supplied with the instrument.

The carbohydrate content was mathematically calculated in the fresh product .The fat was determined in fresh product according to the AOAC (2003) by soxhlet extraction method using petroleum ether (b.p 40$60^{\circ} \mathrm{C}$ ) for sixteen hours. The ether was evaporated on steam bath and the drying was completed at ambient temperature.

The determination of the acetaldehyde was conducted according to the AOAC (2003). The color intensity was measured at $560 \mathrm{~nm}$ using Unicum UV 2100 Spectro photometer, USA. The concentration of acetaldehyde was calculated using a stander curve of pure acetaldehyde.

\section{Microbiological Analysis: -}

MRS, VRBA and Sabourad agar media were used for enumerating, lactic acid bacteria, coliform group and yeast and moulds according to the standard method of dairy products (1984). Bifidiobacterium Sp. was counted on lithium chloride- galactose- agar according to Lapierra et al., (1992), using double layered plat in an aerobic jar.

\section{Sensory evaluation:}

All cereal fermented milk samples were sensory evaluated (flavour, body and texture, and general appearance) by ten staff members of Department of Dairy Science and Technology. Sensory evaluation was carried out using score card estimated by Clark et al (2009) with suggested score guide for designated defect intensitie.

\section{RESULTS AND DISCUSSION}

Effects of different wheat and barley flours concentrations on some properties of bio-yoghurt fermented milk were presented in tables $(1,2,3,4$ and $5)$ and figures (1, 2, 3, 4, 5, and 6) during the storage at $5 \pm 1^{\circ} \mathrm{C}$ for 14 days. It was clear that the $\mathrm{pH}$ of control bio-yoghurt was decreased gradually from 4.97 to 4.48 , while the titratable acidity was increased from 0.755 to 0.882 after 14 days of storage. The addition of wheat flour at 3, 5, and $7 \%$ for preparing the cereal- bioyoghurt had slight affect the $\mathrm{pH}$ and acidity\% of these products . The $\mathrm{pH}$ of $3 \%$ whole wheat was 4.94 and after 14 days. The corresponding values were 4.99 to 4.65 and 5.17 to 4.85 for $5 \%$ and $7 \%$ cereals bio-yoghurt respectively. The rate of decreasing in $\mathrm{pH}$ was lower than that found in control bio-yogurt .Also the rate of increasing the acidity was less than that of control. The acidity of 3, 5, 7\% wwf-cereal bio-yoghurt were 0.793 , 0.803 and 0.898 after one day and $0.898,0.868$ and 1.003 after 14 days respectively. The same trend was found during the storage of barley bio- yoghurt, but the 
rate of $\mathrm{pH}$ decreasing and acidity increasing was higher in barley yoghurt than that in wheat bio- yoghurt. These results are in agreement with that obtained by AbouDonia et al., (1991) during the preparation of cereal culture milk.

The total protein was increased in cereal-fermented bio-yoghurt with increasing the $\%$ of wheat or barley flour added depending on the $\%$ of protein in each. The protein content was $9.7 \%$ in wheat flour and $11.7 \%$ in barley flour.

Soluble Protein/total protein increased during storage and it was higher in wheat flour Bio-yoghurt fermented milk than that in barley bio-yoghurt fermented milk.

Table 1. Effect of different wheat flour concentrations on some chemical properties of bioyoghurt cereal fermented milk during storage

\begin{tabular}{lcccc}
\hline \multicolumn{1}{c}{ Sample } & $\begin{array}{c}\text { Storage Period (days) at } \\
\mathbf{5 \pm 1} \mathbf{C}\end{array}$ & $\mathbf{p H}$ & $\begin{array}{c}\text { Acidity as lactic } \\
\text { acid \% }\end{array}$ & SP/TP \% \\
\hline Control & 1 & 4.97 & 0.755 & 4.060 \\
& 4 & 4.75 & 0.805 & 5.383 \\
& 7 & 4.66 & 0.823 & 6.736 \\
\hline Whole wheat & 14 & 4.48 & 0.882 & 4.932 \\
Flour & 1 & 4.94 & 0.793 & 6.117 \\
$\mathbf{3 \%}$ & 4 & 4.79 & 0.848 & 8.018 \\
\hline Whole wheat & 7 & 4.58 & 0.853 & 5.115 \\
Flour & 14 & 4.20 & 0.898 & 6.821 \\
$\mathbf{5 \%}$ & 1 & 4.99 & 0.803 & 8.220 \\
\hline Whole wheat & 4 & 4.86 & 0.823 & 4.431 \\
Flour & 7 & 4.76 & 0.838 & 7.749 \\
$\mathbf{7 \%}$ & 14 & 4.65 & 0.868 & 9.408 \\
\hline
\end{tabular}

Table 2. Effect of different barley flour concentrations on some chemical properties of bioyoghurt cereal fermented milk during storage

\begin{tabular}{lcccc}
\hline \multicolumn{1}{c}{ Sample } & $\begin{array}{c}\text { Period (days) at Storage } \\
\mathbf{5 \pm 1} \mathbf{1}^{\circ}\end{array}$ & $\mathbf{p H}$ & $\begin{array}{c}\text { Acidity as lactic acid } \\
\mathbf{\%}\end{array}$ & SP/TP \% \\
\hline Control & 1 & 4.97 & 0.755 & 4.060 \\
& 4 & 4.75 & 0.805 & 5.383 \\
& 7 & 4.66 & 0.823 & 6.736 \\
\hline Whole barley & 14 & 4.48 & 0.882 & 3.724 \\
Flour & 1 & 4.45 & 0.847 & \\
$\mathbf{3 \%}$ & 4 & 4.43 & 0.857 & 6.151 \\
& 7 & 4.12 & 0.872 & 7.393 \\
\hline Whole barley & 14 & 4.06 & 0.902 & 3.577 \\
Flour & 1 & 4.31 & 0.862 & 5.211 \\
$\mathbf{5 \%}$ & 4 & 4.23 & 0.867 & 6.498 \\
\hline Whole barley & 7 & 4.05 & 0.887 & 4.336 \\
Flour & 14 & 3.96 & 0.987 & \\
$\mathbf{7 \%}$ & 1 & 4.29 & 0.872 & 5.402 \\
& 4 & 4.13 & 0.882 & 6.492 \\
\hline
\end{tabular}




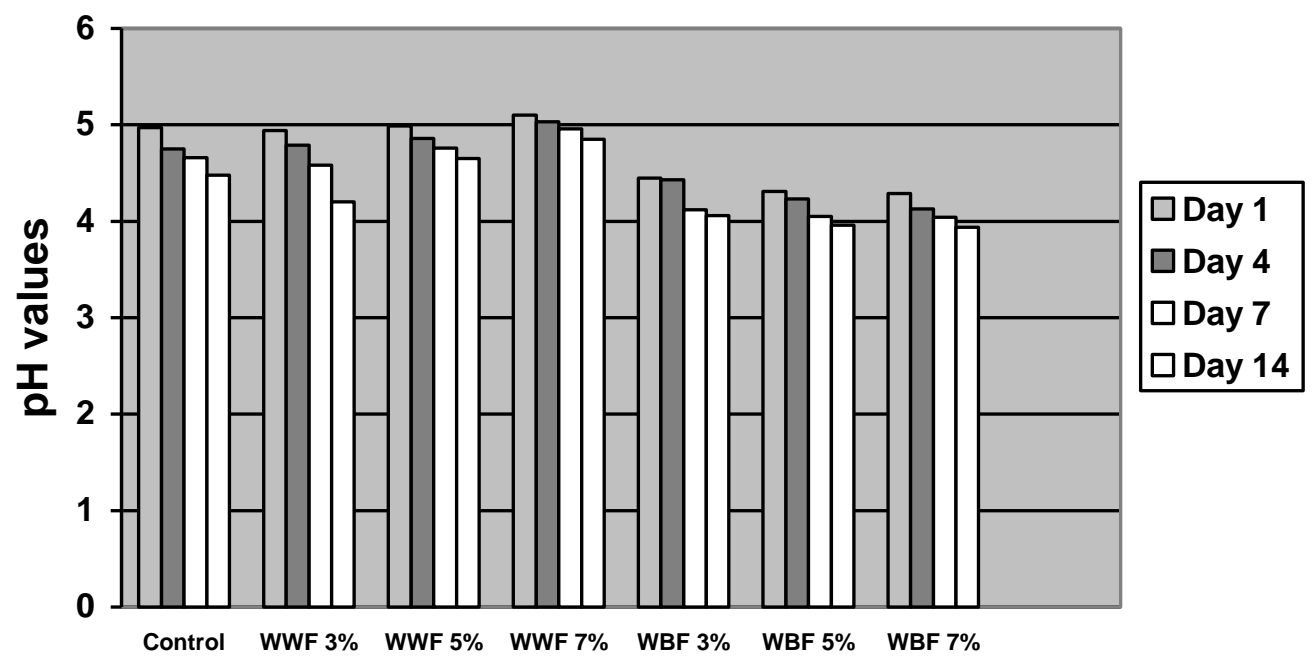

WWF: Whole wheat flour

WBF: Whole barley flour

Fig 1. Effect of different wheat and barley flour concentrations on $\mathrm{pH}$ of bio-yoghurt cereal fermented milk product during storage

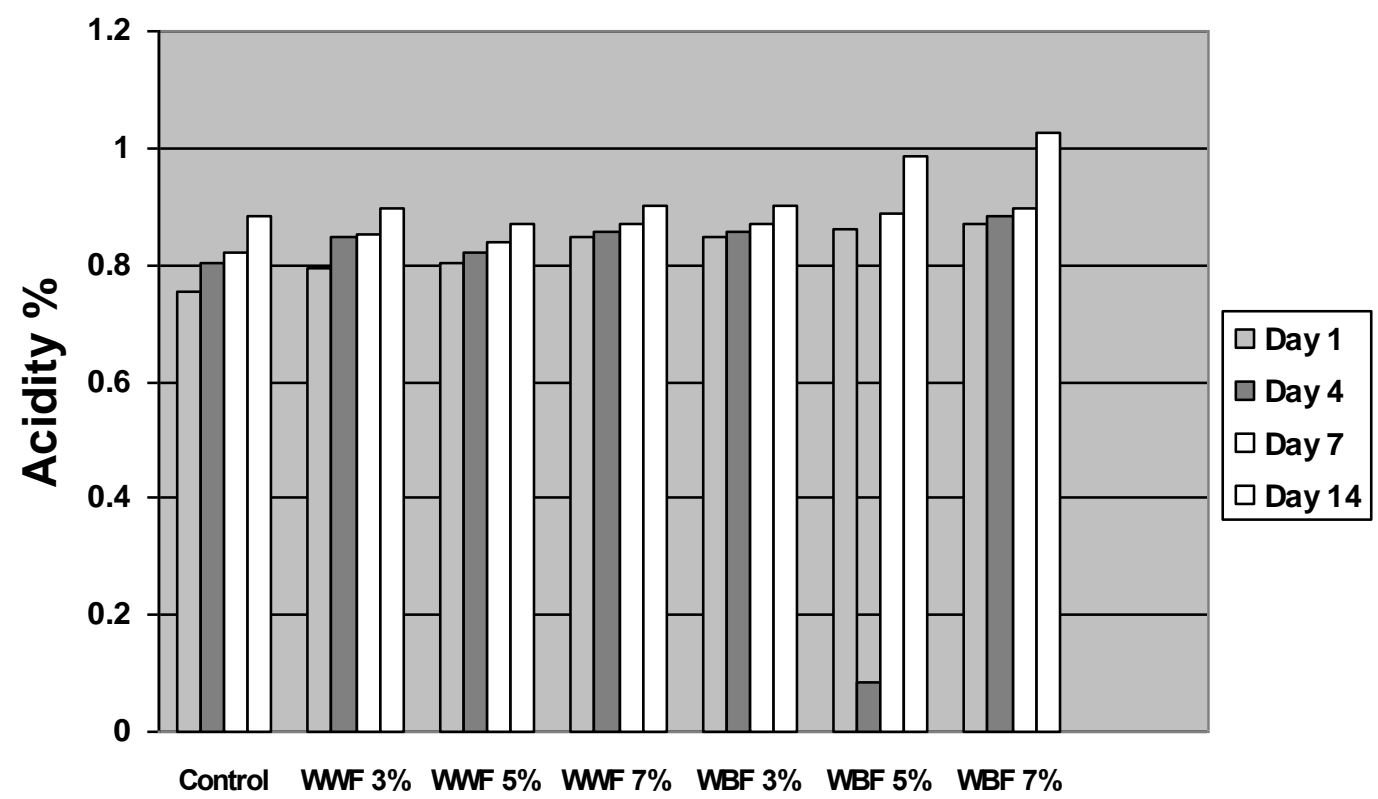

WWF: Whole wheat flour

WBF: Whole barley flour

Fig 2.Effect of different wheat and barley flour concentrations on acidity of bio-yoghurt cereal fermented milk product during storage 


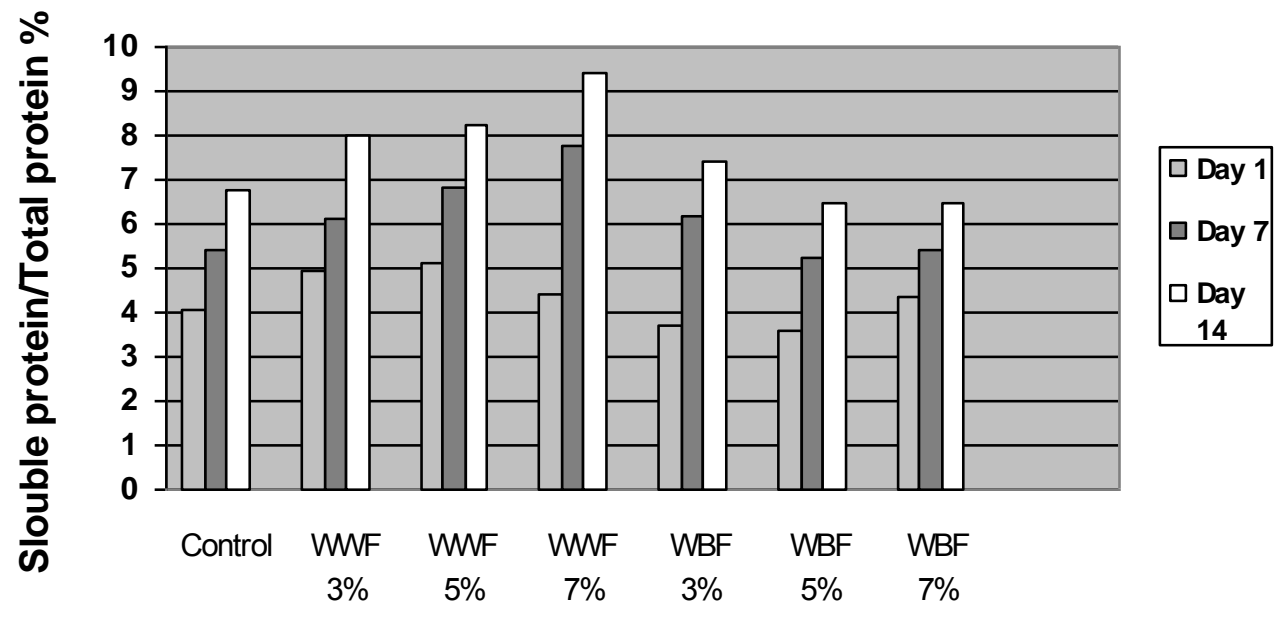

WBF: Whole barley flour

W W F: Whole wheat flour

Fig 3. Effect of different wheat and barley flour concentrations o soluble protein/total protein of bio-yoghurt cereal fermented milk product during storage

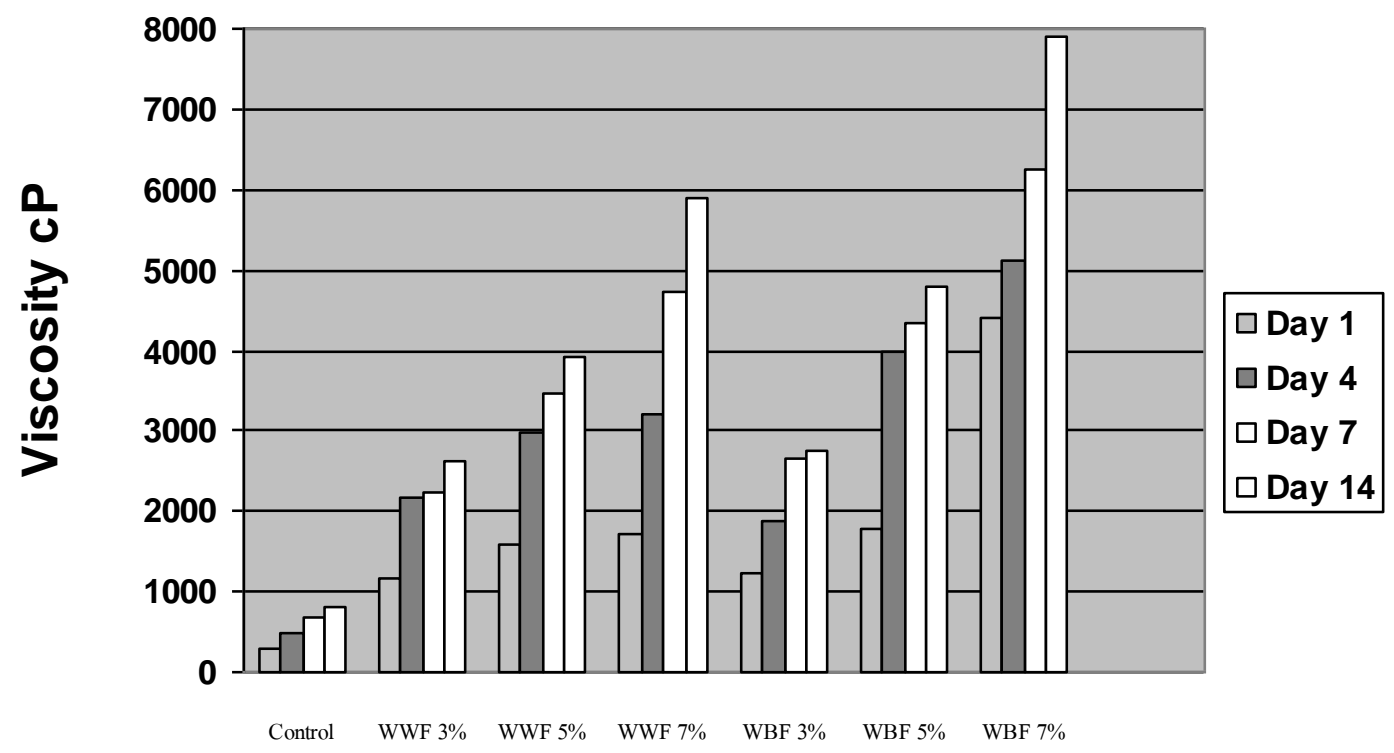

WWF: Whole wheat flour.

WBF: Whole barley flour.

Fig 4. Effect of different wheat and barley flour concentrations on viscosity of bio-yoghurt cereal fermented milk product during storage 


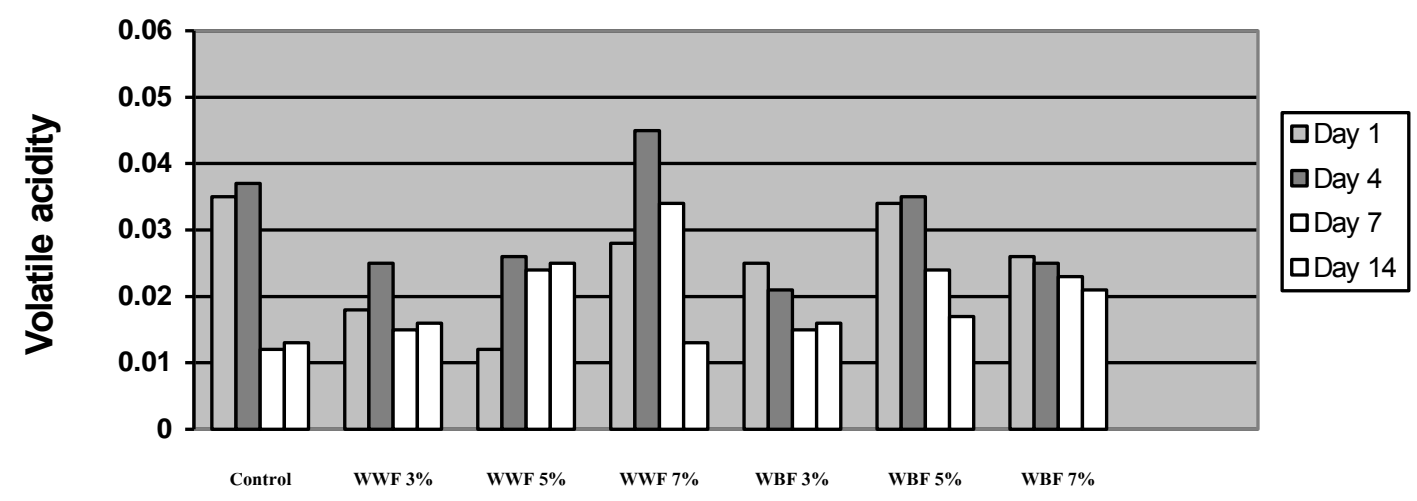

WWF: Whole wheat flour.

WBF: Whole barley flour.

Fig 5. Effect of different wheat and barley flour concentrations on volatile acidity of bioyoghurt cereal fermented milk product during storage

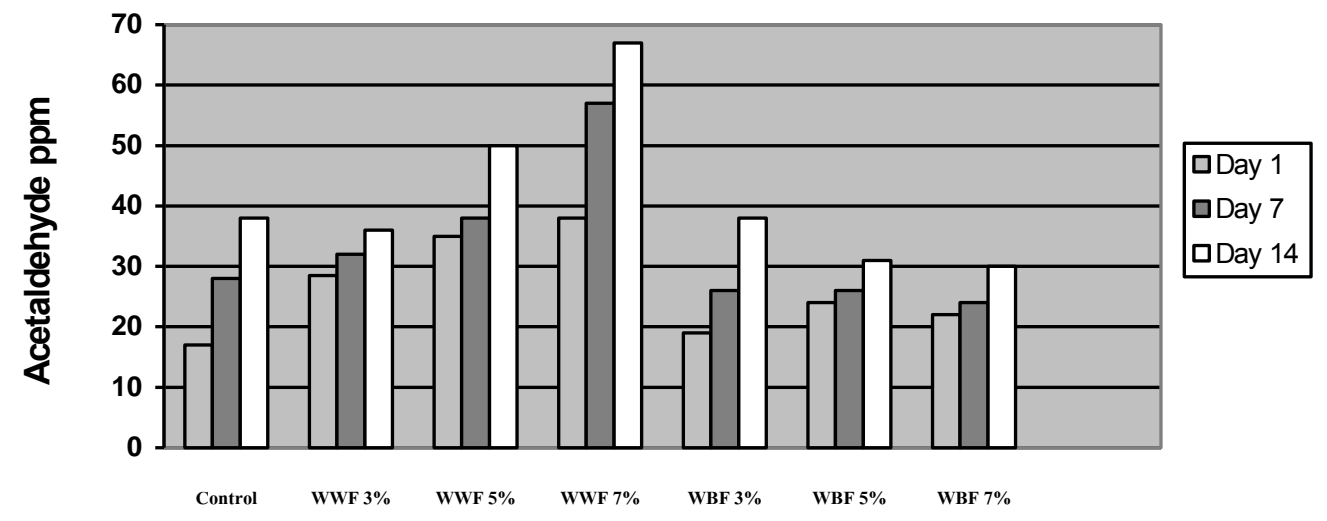

W W F: Whole wheat flour

W B F: Whole barley flour

Fig 6. Effect of different wheat and barley flour concentrations on acetaldehyde of bioyoghurt cereal fermented milk product during storage

The viscosity of bio-yoghurt and bio-yoghurt cereal fermented milk was presented in tables $(3,4)$ and figs (4).The data revealed that the addition of whole wheat or whole barley flours had a great effect on viscosity. The viscosity in fresh bio-yoghurt was $302.87 \mathrm{cP}$ while it was $1160.54,1589.25$ and $1702.09 \mathrm{cP}$ in fresh whole wheat bio-yoghurt with 3,5 and $7 \%$ respectively. The corresponding values in fresh whole barley bio-yoghurt were $1240.74,1778.41$ and $4406.25 \mathrm{cP}$. At the end of storage period (14 days), the viscosity was increased to be $794.77 \mathrm{cP}$ in bio-yoghurt, while the values of viscosity increased to be $2632.47,3915.31$ and 5890.54 $\mathrm{cP}$ in 3,5and 7\% whole wheat bio-yoghurt and 2767.72, 4794.00 and $7887.15 \mathrm{cP}$ in 3, 5 and $7 \%$ in whole barley bio-yoghurt. 
Regarding to the data in tables $(3,4)$ and fig. (5) It was clear that the addition of whole wheat or whole barley flour had slight effect on the volatile acidity during the preparation and storage of bio-yoghurt with different concentrations. The volatile acidity reached $0.035 \%$ in fresh bio-yoghurt and ranged from 0.012 to $0.034 \%$ in cereal bio-yoghurt. The corresponding values after (14 days) of storage were $0.013 \%$ in bioyoghurt and ranged from 0.013 to $0.025 \%$ in cereal bioyoghurt.
Data in tables (3, 4) and fig. (6) Showed that the acetaldehyde content in bio-yoghurt slightly affected by the addition of both whole wheat or whole barley flours with different concentrations during the preparation of cereal bio-yoghurt .The acetaldehyde content was 17 ppm in fresh bio-yoghurt and ranged from 19 to 38ppm in fresh cereal bio-yoghurt. The acetaldehyde content reached $38 \mathrm{ppm}$ in bio-yoghurt after 14 days of storage, while it ranged from $36-67 \mathrm{ppm}$ in whole wheat flour bio-yoghurt and from 30 to $38 \mathrm{ppm}$ in whole barley flour bio- yoghurt.

Table 3. Effect of different wheat flour concentrations on viscosity, volatile acidity and acetaldehyde of bio-yoghurt cereal fermented milk product during storage

\begin{tabular}{lcccc}
\hline \multicolumn{1}{c}{ Sample } & $\begin{array}{c}\text { Storage Period (days) at } \\
\mathbf{5} \mathbf{1}^{\circ} \mathbf{C}\end{array}$ & $\begin{array}{c}\text { Viscosity } \\
\text { (cP) }\end{array}$ & $\begin{array}{c}\text { Volatile acidity } \\
\text { \% }\end{array}$ & $\begin{array}{c}\text { Acetaldehyde } \\
\text { (ppm) }\end{array}$ \\
\hline Control & 1 & 302.87 & 0.035 & 17 \\
& 4 & 479.30 & 0.037 & 28 \\
& 7 & 687.04 & 0.012 & 38 \\
\hline Whole wheat & 14 & 794.77 & 0.013 & 28.5 \\
Flour & 1 & 1160.54 & 0.018 & 32 \\
$\mathbf{3 \%}$ & 4 & 2156.95 & 0.025 & 36 \\
& 7 & 2231.42 & 0.015 & 35 \\
Whole wheat & 14 & 2632.47 & 0.016 & 38 \\
Flour & 1 & 1589.25 & 0.012 & 50 \\
$\mathbf{5 \%}$ & 4 & 2979.0 & 0.026 & 38 \\
& 7 & 3452.00 & 0.024 & \\
Whole wheat & 14 & 3915.31 & 0.025 & 57 \\
Flour & 1 & 1702.09 & 0.028 & 67 \\
\hline
\end{tabular}

Table 4. Effect of different barley flour concentrations on viscosity, volatile acidity and acetaldehyde of bio- yoghurt cereal fermented milk product during storage

\begin{tabular}{lcccc}
\hline Sample & $\begin{array}{c}\text { Storage Period } \\
\mathbf{5 \pm 1} \mathbf{C}\end{array}$ & $\begin{array}{c}\text { Viscosity } \\
(\mathbf{c P})\end{array}$ & $\begin{array}{c}\text { Volatile acidity } \\
\mathbf{\%}\end{array}$ & $\begin{array}{c}\text { Acetaldehyde } \\
\text { (ppm) }\end{array}$ \\
\hline Control & 1 & 302.88 & 0.035 & 17 \\
& 4 & 479.30 & 0.037 & 28 \\
& 7 & 687.04 & 0.012 & 38 \\
\hline Whole barley & 14 & 794.77 & 0.013 & 19 \\
Flour & 1 & 1240.74 & 0.025 & 26 \\
$\mathbf{3 \%}$ & 4 & 1880.00 & 0.021 & 38 \\
& 7 & 2648.76 & 0.015 & 24 \\
\hline Whole barley & 14 & 2767.72 & 0.016 & 26 \\
Flour & 1 & 1778.41 & 0.034 & 31 \\
$\mathbf{5 \%}$ & 4 & 3979.33 & 0.035 & 22 \\
& 7 & 4324.00 & 0.024 & \\
\hline Whole barley & 14 & 4794.00 & 0.017 & 24 \\
Flour & 1 & 4406.25 & 0.026 & 30 \\
$\mathbf{7 \%}$ & 4 & 5111.25 & 0.025 & \\
& 7 & 6256.87 & 0.023 & 0.021 \\
\hline
\end{tabular}


Table 5. Some chemical composition of bio-yoghurt cereal fermented milk product as affected by addition of different concentrations of wheat or barley flour

\begin{tabular}{lcccc}
\hline \multicolumn{1}{c}{ Sample } & Carbohydrate \% & Ash \% & Crude Fibers \% & Fat content \% \\
\hline Control & 4.571 & 0.712 & 0.000 & 3.502 \\
\hline $\begin{array}{l}\text { Whole wheat Flour } \\
\mathbf{3 \%}\end{array}$ & 7.075 & 0.769 & 0.181 & 3.542 \\
\hline $\begin{array}{l}\text { Whole wheat Flour } \\
\mathbf{5 \%}\end{array}$ & 8.597 & 0.807 & 0.314 & 3.562 \\
\hline $\begin{array}{l}\text { Whole wheat Flour } \\
\mathbf{7 \%}\end{array}$ & 10.629 & 0.804 & 0.425 & 3.555 \\
\hline $\begin{array}{l}\text { Whole Barley } \\
\mathbf{3 \%} \quad \text { Flour }\end{array}$ & 6.890 & 0.796 & 0.304 & 3.570 \\
\hline $\begin{array}{l}\text { Whole Barley } \\
\mathbf{5 \%} \quad \text { Flour }\end{array}$ & 8.121 & 0.809 & 0.565 & 3.597 \\
\hline $\begin{array}{l}\text { Whole Barley } \\
\mathbf{7 \%} \quad \text { Flour }\end{array}$ & 10.534 & 0.912 & 0.722 & 3.630 \\
\hline
\end{tabular}

Roushdy et al (1996) found that the acidity and acetaldehyde content were higher in acidophilus or bifidus buttermilk during storage period .Also Ghaleb et al (1998) and El-Sayed et al (1998) estimated the acetaldehyde in fermented milks and obtained the same results.

Table (5) illustrate the percent of carbohydrate, ash, crude fibers and fat in bio-yoghurt and in cereal bioyoghurt supplemented with whole wheat flour or whole barley flour in different concentrations. The carbohydrate in control bio-yoghurt was $4.571 \%$ Adding 3,5 and 7 whole wheat flour in bio-yoghurt increased this percentage $7.075,8.597$ and $10.629 \%$ respectively, the corresponding values in whole barley bio-yoghurt were $6.890,8.121$ and $10.534 \%$. This increase was related to the percent of carbohydrate in each cereal used. The percent of fibers in control bio-yoghurt was nil while in cereal bio-yoghurt, the crude fibers were increased gradually depending on the percent of each whole wheat or whole barley added. It ranged from 0.181 to 0.425 in whole wheat bio-yoghurt and from 0.304 to 0.722 in whole barley bio-yoghurt. It was noticed that percent of crude fiber was higher in barley bio-yoghurt than in whole wheat bio-yoghurt because of its higher content of crude fibers which reached $10.35 \%$. The percent of fat did not affected markedly by the addition of both whole wheat flour or whole barley flour while the ash \% is slightly increased.

Tables 6 and 7 illustrate the changes in $\log$ of c.f.u counts on MRS and on LCSP (Lithium chloride-sodium propionate) in bio-yoghurt with whole wheat flour and with whole barley flour, respectively. The storage of all products either with or without adding cereals had decline. The colony forming units during storage for all concentration of whole cereal flour were used (about 0.3 $\log \mathrm{cpu} / \mathrm{mg}$ ) decrease, on both MRS or LCSP medium. Whereas clear decline was noticed on MRS medium in bio-yoghurt without wheat control $0.705 \log$, (Table 6). On the other hand there were decrease in $\log$ c.f.u values in bio-yoghurt with or without whole barley flour (Table7), but there is no similarity in decreasing values between different treatments and among treatments on both MRS medium or LCSP medium. The highest decrease was on MRS cfu/mg $(0.721 \log )$ in bio-yoghurt with 3\% whole barley flour. The corresponding decreasing values were cfu/mg $(0.705,0.351,0.388 \log )$ for $0 \%, 5 \%$ and $7 \%$ whole barley flour bio-yoghurt, respectively. Furthermore, non of the undesirable microorganisms (coliform, yeast and moulds) were detected in fresh and stored products through the storage period.

Medina and Jordano (1994) studied the survival of constitutive microflora in one batch of fermented milk containing Bifidobacteria during storage at $7^{\circ} \mathrm{C}$.Levels of Streptococcus thermophilus, Lactobacillus bulgaricus and Bifidobacterium spp. in initial population were $2.6 \times$ $10^{8}, 5.1 \times 10^{7}$ and $7.4 \times 10^{6} \mathrm{cfu} / \mathrm{ml}$ respectively. Streptococcus thermophilus slightly increased after 10 days and then decreased. Numbers of Bifidobacterium and Lactobacillus bulgaricus decreased faster during storage. Samona and Robinson (1994) studied the effect of yoghurt cultures on the survival of three species of Bifidobacterium (Bifidobacterium bifidum, Bifidobacterium longum and Bifidobacterium adolescentis) in reconstituted skim milk (12\% total solids) in a combination with 1 of 3 commercial yoghurt cultures. Total counts were recorded for the Bifidobacteria over a growth period of $24 \mathrm{~h}$ and, for samples culturing to $\mathrm{pH} 4.6$ during storage at $5^{\circ} \mathrm{C}$ for up to 21 days. The yoghurt organisms tended to inhibit the growth of Bifidobacteria. Subsequent storage in the presence of the yoghurt cultures did not lead to any significant decrease in numbers. 
Shin et al. (1998) studied the viability of Bifidobacteria in commercially available milk and yoghurt during refrigerated storage. Initial Bifidobacteria and lactic acid bacterial counts in milk decreased from $5 \times 10^{6} \mathrm{cfu} / \mathrm{ml}$ to $1 \times 10^{6}$ and $4 \times 10^{6} \mathrm{cfu} / \mathrm{ml}$. respectively. In yoghurt, Initial Bifidobacteria and lactic acid bacteria counts were $10^{8} \mathrm{cfu} / \mathrm{g}$, respectively. Bifidobacteria in milk and yoghurt remain well above the $10^{6} \mathrm{cfu} / \mathrm{g}$ recommended dose for consumption to receive health benefits of these organisms and conventionally treated milk during low temperature storage at $4{ }^{\circ} \mathrm{C}$ for 4 weeks and they found that the survival of encapsulated probiotic bacteria was higher than free cells bacteria was maintained above the recommended therapeutic minimum $10^{7} \mathrm{cfu} / \mathrm{g}$ throughout the storage. Also, they pointed that the viability of probiotic bacteria in yoghurt from both treatments was not significantly different.

Sensory evaluation of Bio-yoghurt and cereals fermented bio -yoghurt were sensory evaluated and the results were found in tables ( 8 and 9). The addition of whole wheat flour in 3,5 and 7\% had a different effect on the probiotic fermented products, the best effect in flavor, body and texture, appearance and color was noticed at 3\% added whole wheat flour and still the best along the storage period (14days) followed by $5 \%$, while the addition of $7 \%$ had the lowest total score because of high viscosity and unnatural color and still not acceptable at the end of storage. On the other hand the use of whole barley flour at 5\% led to higher scores because of the pleasant taste, body and texture and appearance, followed by 3\% in which the body was slightly weak but there was no appearance of any foreign flavor and the slightly increase of acidity enhanced the flavor. After 2 weeks, 5\% whole barley flour still had the best scores followed by $3 \%$ while in $7 \%$ whole barley flour the unnatural flavor was found. The overall accepted product depending on the sensory evaluation in bio-yoghurt while whole barley flour $5 \%$ had the best results.

From the above results, it could be concluded that either whole wheat or whole barley flour can be used to produce an acceptable cereal fermented milk product as functional foods which may be suitable for elderly persons or infants weaning foods. This formula has a high nutritional value on fiber beside the presence of probiotic bacteria with a lot of health benefits.

\section{Table 6. Changes in microbial counts $\left(\log\right.$ c.f.u $\left.\mathrm{g}^{-1}\right)$ in wheat flour bio-yoghurt during storage at $5 \pm 1{ }^{\circ} \mathrm{C}$}

\begin{tabular}{|c|c|c|c|c|c|c|c|}
\hline \multicolumn{8}{|c|}{ Medium } \\
\hline \multirow[t]{3}{*}{ Sample } & \multicolumn{2}{|c|}{ MRS } & \multicolumn{2}{|c|}{$\begin{array}{l}\text { Lithium chloride - } \\
\text { sodium propionate }\end{array}$} & VRBA & \multicolumn{2}{|c|}{ Sabourad } \\
\hline & \multicolumn{7}{|c|}{ Storage period ( days) } \\
\hline & 1 & 14 & 1 & 14 & 14 & 1 & 14 \\
\hline Control & 6.545 & 6.220 & 5.819 & 5.114 & & & \\
\hline \multicolumn{8}{|l|}{ Whole wheat } \\
\hline Flour $\quad 3 \%$ & 6.484 & 6.176 & 6.556 & 6.255 & & & \\
\hline \multicolumn{8}{|l|}{ Whole wheat } \\
\hline Flour $5 \%$ & 6.554 & 6.236 & 6.602 & 6.301 & & & \\
\hline \multicolumn{8}{|l|}{ Whole wheat } \\
\hline Flour $7 \%$ & 6.512 & 6.220 & 6.611 & 6.312 & - & - & - \\
\hline \multicolumn{8}{|c|}{$\begin{array}{l}\text { Table 7. Changes in microbial counts }\left(\mathrm{Log} \text { c.f.u } \mathrm{g}^{-1}\right) \text { in barley flour bio- yoghurt during } \\
\text { storage at } 5 \pm 1^{\circ} \mathrm{C} \text {. }\end{array}$} \\
\hline \multicolumn{8}{|c|}{ Medium } \\
\hline \multirow[t]{3}{*}{ Sample } & \multicolumn{2}{|c|}{ MRS } & \multicolumn{2}{|c|}{$\begin{array}{c}\text { Lithium chloride -sodium } \\
\text { propionate }\end{array}$} & VRBA & \multicolumn{2}{|c|}{ Sabourad } \\
\hline & \multicolumn{7}{|c|}{ Storage period ( days) } \\
\hline & 1 & 14 & 1 & $14 \quad 1$ & 14 & 1 & 14 \\
\hline Control & 6.545 & 6.220 & 5.819 & 5.114 & & & \\
\hline \multicolumn{8}{|l|}{ Whole Barley } \\
\hline Flour $3 \%$ & 6.667 & 6.502 & 6.182 & 5.461 & & & \\
\hline \multicolumn{8}{|l|}{ Whole Barley } \\
\hline Flour $5 \%$ & 6.699 & 6.627 & 6.324 & 5.973 & & & \\
\hline \multicolumn{8}{|l|}{ Whole Barley } \\
\hline Flour $7 \%$ & 6.597 & 6.279 & 6.531 & 6.143 & & & \\
\hline
\end{tabular}

(-):- Not detected in $0.1 \mathrm{gm}$ 
Table 8. Sensory evaluation of wheat flour bio-yoghurt during storage

\begin{tabular}{lccccc}
\hline \multicolumn{1}{c}{ Sample } & $\begin{array}{c}\text { Storage Period at } \\
\mathbf{5}+\mathbf{1}^{\circ} \mathbf{C} \\
\mathbf{( d a y s )}\end{array}$ & $\begin{array}{c}\text { Flavor } \\
\mathbf{( 1 0 )}\end{array}$ & $\begin{array}{c}\text { Body and } \\
\text { texture } \\
\mathbf{( 5 )}\end{array}$ & $\begin{array}{c}\text { Appearance } \\
\text { and color } \\
\mathbf{( 5 )}\end{array}$ & $\begin{array}{c}\text { Total } \\
\mathbf{( 2 0 )}\end{array}$ \\
\hline Control & 1 & 9 & 3 & 4 & 16 \\
& 7 & 8 & 3 & 4 & 15 \\
\hline Whole wheal & 14 & 7 & 3 & 3 & 14 \\
Flour 3\% & 1 & 9 & 4 & 4 & 17 \\
& 7 & 9 & 4 & 4 & 17 \\
\hline Whole wheat & 14 & 9 & 4 & 4 & 17 \\
Flour 5\% & 1 & 9 & 3 & 4 & 16 \\
& 7 & 9 & 3 & 4 & 15 \\
\hline Whole wheat & 14 & 8 & 3 & 4 & 12 \\
Flour 7\% & 1 & 7 & 2 & 2 & 11 \\
\hline
\end{tabular}

Table 9. Sensory evaluation of barley flour bio-yoghurt during storage

\begin{tabular}{|c|c|c|c|c|c|}
\hline Sample & $\begin{array}{c}\text { Storage Period at } 5 \pm 1^{\circ} \mathrm{C} \\
\text { (days) }\end{array}$ & $\begin{array}{l}\text { Flavor } \\
(\mathbf{1 0})\end{array}$ & $\begin{array}{c}\text { Body and } \\
\text { texture } \\
(5)\end{array}$ & $\begin{array}{l}\text { Appearance } \\
\text { and color } \\
\text { (5) }\end{array}$ & $\begin{array}{l}\text { Total } \\
(20)\end{array}$ \\
\hline \multirow[t]{3}{*}{ Control } & 1 & 9 & 3 & 4 & 16 \\
\hline & 7 & 8 & 3 & 4 & 15 \\
\hline & 14 & 7 & 3 & 3 & 14 \\
\hline Whole barley & 1 & 9 & 4 & 4 & 17 \\
\hline \multirow[t]{2}{*}{ Flour 3\% } & 7 & 9 & 4 & 4 & 17 \\
\hline & 14 & 7 & 4 & 4 & 15 \\
\hline Whole barley & 1 & 9 & 5 & 4 & 18 \\
\hline \multirow[t]{2}{*}{ Flour 5\% } & 7 & 9 & 5 & 4 & 18 \\
\hline & 14 & 8 & 5 & 4 & 17 \\
\hline Whole barley & 1 & 9 & 3 & 2 & 16 \\
\hline \multirow[t]{2}{*}{ Flour 7\% } & 7 & 9 & 3 & 2 & 16 \\
\hline & 14 & 6 & 3 & 2 & 13 \\
\hline
\end{tabular}

\section{REFERENCES}

Abd El-Rahman, A.M; A.N.Hassan and E.E.Kheadr (2000).Stability effect of bacterial capsules in making frozen yoghurt .Egypt.J.Dairy Sci.28:195-209.

Abou-Donia, S.A; Attia.I.A; Khattab.A.A.and El-Sheawi, Z. (1991).Studies on the formation of fermented milk for infantile and geriatric nutrition. Egyptian J.Dairy Sci 19:283-199.

AOAC (2003).Official Method of Analysis of the Association of Official Analytical Chemist $15^{\text {th }}$ Ed. Arlington Virginia, USA.

Clark.S, Costello.M, Drake.M.and Bodyfelt.F (2009).The Sensory evaluation of dairy products .Second edition, Springer.

Diplock,A.T., Charleux ,J.L., Crozier- Willi, G.KoK, F,J., Rice-Evans, C.,Roberfroid, M., Stahl,W.and Vina- Ribes, J.(1998). Functional food science and defence against reactive oxidative species.Br.J.Nutr., 80 Suppl 1: S77
El- Sayed E.M.; A.A.Hefny; F.A.Saleh and J.A.Abd El-Gawad (1998). Bifidobacteria as a starter for the manufacture of soy - yoghurt products .In Proc $.7^{\text {th }}$ Egyptian Conf.Dairy Sci.8Tech., 241-250.

Ghaleb, H.M.; N.M.Hanafy and A.A.El-Ghandour. (1998).Some trials to produce yoghurt of low cholesterol content. (2): Bacterial cholesterol assimilation .In Proc .7 ${ }^{\text {th }}$ Egyptian Conf .Dairy Sci\&Tech. $251-260$.

Kneifel, W., Mattila-Samdholm, T and Van Wright, A.(1999) Cited from probiotic bacteria .Detection and Estimation in fermented and non- fermented dairy products page .Pp. 1783 - 1788 .

Lapierra, L.P.; P. Undeland and L. J.Cox (1992). Lithium chloride, Sodium propionate agar for the enumeration of bifidobacteria in fermented dairy products. J. Dairy Sci., 75 (5):1192.

Medina, L.M.and Jordano, R. (1994).Survival of constitute microflora in commercially fermented milk containing bifidobacteria during refrigerated storage .J.Food Prot., 58(1):70-75.Cited from Int.Dairy J., 7:349-356. 
Roushdy, I.M.; Ali, A.A.and El-Kenany, Y.M. (1996).Production of acidophilus and bifidus buttermilks from buffaloe's milk .Egypt j. FoodSci. 24:785-793.

Saarela, M.(2007).Functional dairy products, Volume 2.CRCpress, New York, Washington, DC, 540 pp.

Sanders, M.E. (2003).Probiotic considerations for human health .Nutr.Rev.61 (3):91-99.

Savadogo, A.; Ouattara C.A.T.; Bassole, I.H.N. and Traore S.A. (2006).Bacteriocins and lactic acid bacteria- a minireview. African J.Biotechnol., 5:678-683.
Samona, A. and Robinson, R.K. (1994).Effect of yoghurt cultures on the survival of bifidobacteria in fermented milks.J.The Society of Dairy Tech.47 (2):58 - 60.

Shin, H.S; J.H.Lee; JJ.Pestka and Z.Ustuno. (1998).Viability of bifidobacteria commercial dairy products during refrigerated storage .J.Dairy Sci.79, Suppl.1, 124.

Standard methods for the Examination of Dairy Products (1984). Pub. American public Healthe Association.

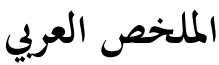

\section{تحضير ألبان متخمرة داعمة للحيوية مدعمة بالحبوب}

$$
\begin{aligned}
& \text { عفت جودة, ملك عباس، ماريان فرج } \\
& \text { أيضـاً زيادة في كل من البروتين الكلي ومحتوى الألياف في المنتج } \\
& \text { بـزيادة نسبة الإضـافات مـن مطحسون الحبـوب. كمـا أظهرت نسبة } \\
& \text { البروتـين الـذائب الى البروتـين الكلـي زيادة أثنــاء التخـزين في كل مـن } \\
& \text { البيويوغورت المدعمين بمطحون الشعير والقمح وذلك بسبب التحلل } \\
& \text { البروتيني بواسطة الميكروبات. } \\
& \text { أدى إضـافة مطحون القمح والشعير الى زيادة اللزوجة. ولم يظهر } \\
& \text { التحليل الميكروبي نمو أي من الميكروباتالغير مرغوبة مثل التابعة لمجموعة إنها } \\
& \text { بكتريا الكوليفورم أو الخمائر أوالفطريات حتى فاية التخزين. } \\
& \text { وأظهر التقييم الحسي تقبـل واضـح للبيويوغـورت المـدعم بالقمـح } \\
& \text { بنسبة 3\% والمدعم بالشعير بنسبة 5٪. } \\
& \text { تمثل جزء من الوجبة اليومية. }
\end{aligned}
$$

